\title{
Model Pembelajaran Kuantum dengan Metode Snowball untuk Meningkatkan Prestasi Belajar Matematika Siswa Kelas I Semester I
}

\section{Ni Ketut Sari \\ SD N 4 Tianyar, Karangasem, Indonesia}

\section{A R T I C L E I N F O \\ Article history:}

Received 19

November 2017

Received in revised

form

6 Januari 2018

Accepted 12 Januari 2018

Available online 20

Februari 2018

Kata Kunci:

model pembelajaran

Kuantum,

metode Snowball,

prestasi belajar.

Keywords:

Quantum learning

model,

Snowball method,

learning

achievement.
A B S T R A K

Penelitian ini dilaksanakan di SD Negeri 4 Tianyar di Kelas I Semester I Tahun Pelajaran 2016/2017 yang kemampuan siswanya untuk mata pelajaran Matematika masih rendah. Tujuan penelitian tindakan kelas ini adalah untuk mengetahui apakah penerapan model pembelajaran Kuantum dengan metode Snowball dapat meningkatkan prestasi belajar matematika siswa. Metode pengumpulan datanya adalah tes prestasi belajar. Metode analisis datanya adalah deskriptif. Hasil yang diperoleh dari penelitian ini adalah penerapan model pembelajaran Kuantum dengan metode Snowball dapat meningkatkan prestasi belajar matematika siswa. Ini terbukti dari hasil yang diperoleh pada pada awalnya53,75 setelah diberikan tindakan pada siklus I meningkat menjadi57,66 dan pada siklus II meningkat lagi menjadi64,22. Kesimpulan yang diperoleh dari penelitian ini adalah penerapan model pembelajaran Kuantum dengan metode Snowball dapat meningkatkan prestasi belajar matematika siswa SD Negeri 4 Tianyar Kelas I Semester I Tahun Pelajaran 2016/2017.

\section{A B S T R A C T}

This study was conducted at SD Negeri 4 Tianyar at the first grade in the first semester in the school year 2016/2017 in which the students still had a low achievement in mathematics. This classroom action research was aimed at finding whether quantum teaching model with Snow Ball method could increase the students' mathematichal learning achievement. The data were collected by learning achievement test and analyze descriptively. The results obtained in this study showed that quantum teaching model with snow ball method can increase students' mathematical learning achievement. This was shown by the result in which initially the score was 53.75, after giving an action in cycle 1 it increased to 57.66 and in cycle 2 it increased again to 64.22. It can be concluded that quantum teaching model with the snow ball method can increase mathematical learning achievement in the first grade students in the first smester at SD Negeri 4 Tianyar in the school year 2016/2017. 


\section{Pendahuluan}

Pendidikan adalah salah satu cara yang harus dilakukan untuk mengikuti perkembangan dunia ini, karena pendidikan adalah alat yang dapat digunakan untuk mengukur daya saing sumber daya manusia dimanapun. Di dalam pendidikan terdapat tujuan-tujuan yang harus dicapai oleh siswa siswa maupun pendidik, tujuan pendidikan dapat dicapai apabila siswa tidak hanya pasif menerima pelajaran, tetapi juga ikut aktif melibatkan diri di dalam proses pembelajaran tersebut (Nugroho, 2015). Undang-undang Nomor 20 Tahun 2003 tentang Sistem pendidikan Nasional menyebutkan, bahwa pendidikan nasional berfungsi mengembangkan kemampuan dan membentuk watak serta peradaban bangsa yang bermartabat dalam rangka mencerdaskan kehidupan bangsa. Oleh karena itu pendidikan bertujuan untuk mengembangkan potensi peserta didik agar menjadi manusia yang beriman dan bertakwa terhadap Tuhan Yang Maha Esa, berahlak mulia, sehat, berilmu, cakap, kreatif, mandiri, dan menjadi warga negara yang demokratis serta bertanggung jawab (Trianto, 2007). Tercapai tidaknya tujuan pengajaran salah satunya adalah terlihat dari prestasi belajar yang diraih siswa. Dengan prestasi yang tinggi, para siswa mempunyai indikasi berpengetahuan yang baik (Hamdu, 2011).

Pendidikan memiliki peranan yang penting bagi pengembangan kualitas pendidikan. Melalui pendidikan setiap peseta didik disediakan berbagai kesempatan belajar untuk meningkatkan pengetahuan, keterampilan, dan sikap untuk dapat menyesuaikan diri dengan kehidupan masyarakat (Dewi, 2014). Berbagai upaya telah dilakukan guna meningkatkan mutu pendidikan, dengan harapan akan dapat menciptakan pendidikan yang berkualitas. Salah satu upaya yang telah dilakukan adalah dengan pengembangan kurikulum. Pengembangan kurikulum saat ini, menekankan pada bagaimana siswa belajar dan bukan apa yang dipelajari siswa. Pengembangan kurikulum saat ini juga mengubah dari pembelajaran yang semula hanya transfer ilmu pengetahuan kepada siswa, menjadi bagaimana siswa itu belajar dengan sendirinya dan menepatkan seorang guru sebagai fasilitator yang mampu memotivasi peserta didik. Semua hal tersebut telah dilakukan sebagai upaya meningkatkan kualitas pendidikan, sehingga dapat menciptakan pendidikan yang berkualitas (Sandi, 2014).

Pendidikan akan lebih bermakna bagi siswa apabila pengetahuan dibangun dengan dasar informasi yang diperoleh secara alami. Hal tersebut dapat terjadi apabila proses belajar mengajar terjadi manakala ada interaksi antara guru dengan siswa dan antara siswa dengan siswa. Dalam interaksi tersebut, guru memerankan fungsi sebagai pengajar, pemimpin belajar, dan fasilitator belajar, sedangkan siswa berperan sebagai pelajar atau individu yang belajar (Irawan, 2014). Sejalan dengan hal tersebut, peningkatan kualitas sumber daya manusia dan menyiapkan peserta didik dalam sistem persekolahan perlu dibantu dalam memecahkan masalah belajar (Wardhiana, 2014). Dampak perkembangan IPTEK terhadap proses pembelajaran adalah diperkayanya sumber dan media pembelajaran, seperti buku teks, modul, overhead transparansi, film, video, televise, slide, hypertext, dan web. Guru professional dituntut mampu memilih dan juga memanfaatkan berbagai jenis media pembelajaran yang ada di sekitar (Pratama, 2014). Untuk tujuan tersebut, lingkungan belajar harus dibangun sedemikian rupa untuk memberikan pemahaman dan menjelaskan secara kongkret teori-teori atau konsep-konsep yang disampaikan kepada siswa. Ilmu pengetahuan harus dibangun secara bertahap dan sedikit demi sedikit sesuai dengan tahap perkembangan kemampuan siswa. Pembelajaran akan terasa baik apabila dalam diri siswa tumbuh rasa ingin tahu, mencari jawaban atas pertanyaan, memperluas dan memperdalam pemahaman dengan menggunakan metode yang efektif. Karena Rendahnya keaktifan siswa dalam mengikuti pembelajaran mengakibatkan rendahnya keberhasilan belajarnya (Jampel,2017). Rasa ingin tahu siswa muncul dan terlihat ketika sudah mulai mengajukan pertanyaan-pertanyaan. Pertanyaan inilah nantinya yang akan menjadi bahan pembelajaran untuk dicari jawabannya bersama-sama antara guru dan siswa. Agar mampu menjawab semua pertanyaan yang dilontarkan siswa dan memberikan dampak yang baik terhadap kelangsungan pembelajaran mereka, seorang guru harus benar-benar memiliki pengetahuan yang mendalam tentang materi yang diajarkan sehingga dia layak disebut seorang guru yang profesional serta memiliki kompetensi.

Kompentensi merupakan perpaduan pengetahuan, keterampilan, nilai dan sikap yang di refleksikan dalam kebiasaan berpikir dan bertindak, (Ashan, 1981) mengemukakan bahwa kompetensi diartikan sebagai pengetahuan, keterampilan, dan kemampuan yang dikuasai oleh seseorang yang telah menjadi bagian dari dirinya, sehingga ia dapat melakukan perilaku-perilaku kognitif, efektif dan psikomotorik dengan sebaik-baiknya. Untuk itu di sekolah dasar perlu diajarkan lima pokok mata pelajaran yaitu IPA, IPS, Bahasa Indonesia, PKn, dan Matematika. Salah satu tujuan pembelajaran matematika adalah kemampuan pemecahan masalah (Widiyaningsih, 2013). Matematika sebagai disiplin ilmu perlu dikuasai dan dipahami dengan baik oleh segenap lapisan masyarakat, terutama siswa sekolah formal (Darkasyi, 2014). Dalam pembelajaran matematika, materi yang satu mungkin merupakan merupakan prasyarat bagi materi lainnya, atau konsep yang satu diperlukan untuk menjelaskan konsep 
yang lainnya. Sebagai ilmu yang saling berkaitan, dalam hal ini siswa diharapkan memiliki kemampuan untuk memecahkan persoaalan - persoalan matematika yang memiliki kaitan terhadap materi yang dipelajari sebelumnya. Kemampuan ini disebut dengan kemampuan koneksi matematika (Linto, 2012). Namun pada kenyataannya, dalam pembelajaran terlihat siswa masih sulit menghubungkan materi yang mereka pelajari dengan materi prasyarat yang sudah mereka kuasai. Konsep - konsep yang telah dipelajari tidak bertahan lama dalam ingatan siswa, akibatnya kemampuan koneksi mereka belum optimal. Hal ini terlihat dari nilai siswa kelas I semester I tahun pelajaran 2016/2017 rendah dengan ratarata 53,75. Rata-rata ini jauh di bawah KKM mata pelajaran Matematika di SD Negeri 4 Tianyar, yaitu 60. Hanya $44 \%$ dari 32 orang siswa yang mampu menuntaskan pembelajaran matematikanya. Untuk meningkatkan penguasaan siswa terhadap materi pelajaran, peneliti melaksanakan perbaikan pembelajaran melalui penelitian tindakan kelas menggunakan model pembelajaran, strategi dan metode yang tepat.

Strategi pembelajaran yang digunakan merupakan hal yang sangat penting agar pembelajaran dapat berjalan secara efektif dan efisien (Latipah, 2010). Dan dengan pertimbangan peneliti memilih model pembelajaran Kuantum dan metode Snowball mengingat model dan metode ini sesuai teori mampu membuat peserta didik aktif dalam belajar dan giat dalam menemukan permasalahan yang ada. Berdasarkan uraian di atas, peneliti mengangkat masalah tersebut untuk diteliti dalam suatu penelitian tindakan kelas sebagai upaya perbaikan pembelajaran Matematika yang diberi judul, Penerapan Model Pembelajaran Kuantum dengan Metode Snowball untuk Meningkatkan Prestasi Belajar Matematika Siswa Kelas I Semester I SD Negeri 4 Tianyar Tahun Pelajaran 2016/2017.

Penelitian yang baik sangat berhubungan dengan kebenaran teori yang disampaikan. Teori-teori para ahli merupakan dasar yang harus diikuti agar penelitian menjadi lebih sempurna. Beberapa pendapat ahli disampaikan pada paparan berikut ini. Bobby DePorter, 1992 (dalam Udin Saifudin Sa'ud, 2008: 125) beranggapan bahwa metode belajar Kuantum sesuai dengan cara kerja otak manusia dan cara belajar manusia pada umumnya dengan model Super Camp yang dikembangkan bersama kawankawannya pada awal tahun 1980an, prinsip-prinsip dan model pembelajaran Kuantum menentukan bentuknya. Pembelajaran Kuantum berdasarkan pada landasan konteks yang menyenangkan dan situasi penuh kegembiraan. Model ini dicetuskan oleh seorang pendidik berkebangsaan Bulgaria yang bernama Georgi Lozanov yang melakukan uji coba tentang sugesti dan pengaruhnya terhadap hasil belajar, teorinya yang terkenal tersebut Suggostology. Menurut Lazanov, pada prinsipnya sugesti itu mempengaruhi hasil belajar. Kaifa, 1999 (dalam Udin Saifudin, 2008: 125) mengatakan bahwa pembelajaran Kuantum sebagai salah satu model, strategi dan pendekatan pembelajaran khususnya menyangkut keterampilan guru dalam merancang, mengembangkan dan mengelola sistim pembelajaran sehingga guru mampu menciptakan suasana pembelajaran yang efektif, menggairahkan dan memiliki, keterampilan hidup. Selanjutnya Udin (2008: 126) mengatakan bahwa pembelajaran Kuantum sebagai salah satu alternatif pembaharuan pembelajaran, menyajikan petunjuk praktis dari spesifik untuk menciptakan lingkungan belajar yang efektif dan bagaimana menyederhanakan proses belajar sehingga memudahkan belajar siswa. Metode pembelajaran sangat menentukan keberhasilan anak didik dalam menuntut ilmu. Hal ini merupakan salah satu yang tidak boleh diabaikan oleh tenaga pendidik karena metode pembelajaran berkedudukan sebagai salah satu komponen yang ikut ambil bagian bagi keberhasilan kegiatan pembelajaran. Diskusi kelompok merupakan suatu pengalaman belajar yang dapat diterapkan dalam segala bidang studi. Akan tetapi harus disesuaikan dengan tujuan instruksional yang akan dicapai serta bahan pelajaran yang diajarkan. Diskusi kelompok model Snowball merupakan salah satu strategi belajar mengajar dengan kadar keaktifan yang tinggi. Banyak hal yang harus kita perhatikan dalam diskusi kelompok, diantaranya materi, tempat duduk siswa serta banyaknya jumlah kelompok karena ketiga hal tersebut sangat berpengaruh dalam keefektifan diskusi itu sendiri. Menurut Suprijono (2009) model pembelajaran Snowball Throwing adalah model pembelajaran yang memberikan pengalaman kepada siswa melalui pembelajaran terpadu dengan menggunakan proses yang saling berkaitan dalam situasi dan konteks komunikasi alamiah baik sosial, sains, hitungan dan lingkungan pergaulan. Dibentuk kelompok yang diwakili ketua kelompok untuk mendapatkan tugas dari guru kemudian masing masing siswa membuat pertanyaan yang dibentuk seperti bola (kertas pertanyaan) lalu dilempar ke siswa lain yang masing masing siswa menjawab pertanyaan dari yang diperoleh. Metode Snowball Throwing merupakan pendekatan yang berpusat pada siswa (Putri, 2014).

Snowball merupakan jenis pembelajaran yang dirancang untuk mempengaruhi pola interaksi siswa dan sebagai alternatif terhadap struktur kelas tradisional. Model Snowball merupakan salah satu strategi belajar mengajar dengan kadar keaktifan yang tinggi. Metode ini biasa dilakukan oleh beberapa kelompok yang terdiri dari lima sampai delapan orang yang memiliki kemampuan merumuskan pertanyaan yang ditulis dalam sebuah kertas menyerupai bola. Kemudian, kertas itu dilemparkan kepada kelompok lain yang untuk ditanggapi dengan menjawab pertanyaan yang dilemparkan tersebut (Widodo, Jurnal 
Pendidikan Penabur: Desember 2009). Safitri (2011) menyatakan bahwa model pembelajaran kooperatif tipe Snowball Throwing memiliki beberapa keunggulan yaitu (1) Melatih kesiapan siswa dalam merumuskan pertanyaan dengan bersumber pada materi yang diajarkan serta saling memberikan pengetahuan; (2) Siswa lebih memahami dan mengerti secara mendalam tentang materi pelajaran yang dipelajari. Hal ini disebabkan karena siswa mendapat penjelasan dari teman sebaya yang secara khusus disiapkan oleh guru; (3) Dapat membangkitkan keberanian siswa dalam mengemukakan pertanyaan kepada teman lain maupun guru; (4) Melatih siswa menjawab pertanyaan yang diajukan oleh temannya dengan baik; (5) Merangsang siswa mengemukakan pertanyaan sesuai dengan topik yang sedang dibicarakan dalam pelajaran tersebut; (6) Dapat mengurangi rasa takut siswa dalam bertanya kepada teman maupun guru; (7) Siswa akan lebih mengerti makna kerjasama dalam menemukan pemecahan suatu masalah; (8) Siswa akan memahami makna tanggung jawab; (9) Siswa akan lebih bisa menerima keragaman atau heterogenitas suku, sosial, budaya, bakat dan intelegensi; (10) Siswa akan terus termotivasi untuk meningkatkan kemampuannya.

Dalam setiap metode pembelajaran pasti ada saja yang membedakan metode yang satu dengan yang lainnya, baik itu dalam pelaksanaannya dan lain sebagainya. Begitu juga dengan metode Snow Ball ini. Dalam pelaksanaannya dibentuk kelompok yang diwakili ketua kelompok untuk mendapat tugas dari guru kemudian masing-masing siswa membuat pertanyaan yang dibentuk seperti bola (kertas pertanyaan) lalu dilempar ke siswa lain yang masing-masing siswa menjawab pertanyaan dari bola yang diperoleh.

Prestasi belajar yang merupakan tujuan akhir dari penyelenggaraan proses belajar adalah satu kesatuan kata yang tidak dapat dipisahkan. Untuk mengetahui prestasi belajar peserta didik biasanya dilakukan evaluasi terhadap materi belajar yang telah diberikan. Seberapa besar peserta didik mampu memberikan (feed back) dari setiap evaluasi yang diberikan, demikianlah gambaran prestasi belajar yang ia miliki. Namun dalam banyak sumber yang diperoleh ditemukan berbagai pengertian dari para ahli menyangkut hal tersebut, yang masing-masing mereka berpendapat sesuai dengan sudut pandang masing-masing.

Nurkencana (1986 : 62) mengemukakan bahwa prestasi belajar adalah hasil yang telah dicapai atau diperoleh anak berupa nilai mata pelajaran. Ditambahkan bahwa prestasi belajar merupakan hasil yang mengakibatkan perubahan dalam diri individu sebagai hasil dari aktivitas dalam belajar. Benyamin S. Bloom (dalam Nurman, 2006: 36), prestasi belajar merupakan hasil perubahan tingkah laku yang meliputi tiga ranah kognitif terdiri atas: pengetahuan, pemahaman, aplikasi, analisis, sintesis, dan evaluasi. Saifudin Azwar (1996:44) prestasi belajar dapat dioperasionalkan dalam bentuk indikator-indikator berupa nilai raport, indeks prestasi studi, angka kelulusan dan predikat keberhasilan. Agus Suprijono (2011: 4) berpendapat bahwa prinsip belajar itu ada tiga: Pertama, prinsip belajar adalah perubahan perilaku. Kedua, belajar merupakan proses yang terjadi karena didorong kebutuhan dan tujuan yang ingin dicapai, dan prinsip yang ketiga adalah belajar merupakan bentuk pengalaman.

Tujuan mendorong seseorang untuk melakukan suatu kegiatan, demikian juga dalam belajar, sebagaimana pendapat yang dikemukakan oleh Sardiman (2011) yang dikutif dari Muzakki (2012: 16-17) bahwa tujuan belajar pada umumnya ada tiga macam, yaitu: 1) untuk mendapatkan pengetahuan, 2) penanaman konsep dan keterampilan, 3) pembentukan sikap. Menurut Sanjaya menyebutkan beberapa faktor yang mempengaruhi keberhasilan dalam pembelajaran yang berorientasi pada aktivitas belajar siswa sebagai berikut: a) Guru, Guru merupakan ujung tombak dalam proses pembelajaran yang sa-ngat mempengaruhi keberhasilan aktivitas belajar siswa karena guru berha-dapan langsung dengan siswa. Beberapa hal yang mempengaruhi keberha-silan aktivitas belajar siswa yang ada pada guru antara lain: kemampuan guru, sikap profesionalitas guru, latar belakang pendidikan guru, dan pengala-man mengajar. b) Sarana belajar, keberhasilan implementasi pembelajaran berorientasi aktivitas siswa juga dipengaruhi oleh ketersediaan sarana belajar. Yang termasuk keterse-diaan sarana itu meliputi ruang kelas dan setting tempat duduk siswa, media, dan sumber belajar. c) Lingkungan belajar, merupakan faktor lain yang dapat mempenga-ruhi keberhasilan pembelajaran berorientasi aktivitas siswa. Ada dua hal yang termasuk ke dalam faktor lingkungan belajar yaitu lingkungan fisik dan lingkungan psikologis. Lingkungan fisik meliputi keadaan dan kondisi sekolah, misalnya jumlah kelas, laboratorium, perpustakaan, kantin, kamar kecil yang tersedia; serta di mana lokasi sekolah itu berada

Menyangkut belum berhasilnya siswa mencapai ketuntasan belajar yang diinginkan dan upaya pemecahan yang akan dilakukan, maka peneliti berhasil merumuskan masalah dalam penelitian ini sebagai berikut:Apakahapakah penerapan model pembelajaran Kuantum dengan metode Snowball dapat meningkatkan prestasi belajar matematika siswa SD Negeri 4 Tianyar Kelas I Semester I Tahun Pelajaran 2016/2017? Dan tujuan penelitian ini dimaksudkan untuk mengetahui peningkatan prestasi belajar matematika yang terjadi setelah diterapkannya langkah-langkah model pembelajaran kuantum dengan metode Snowball dalam proses pembelajaran. 


\section{Metode Penelitian}

Penelitian ini berlokasi di SD Negeri 4 Tianyar.Rancangan penelitian dalam penelitian tindakan kelas ini diadopsi dari rancangan yang disajikan oleh Depdiknas seperti pada gambar berikut:

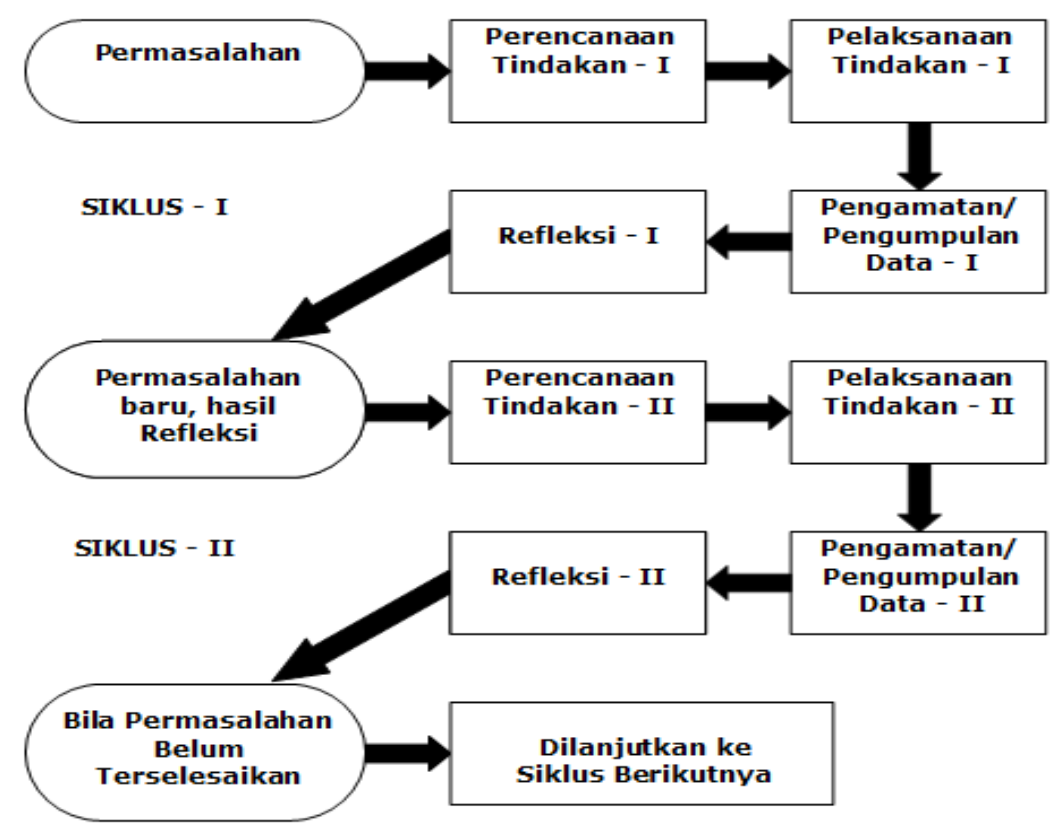

Gambar 01. Rancangan Penelitian Tindakan Depdiknas (2011: 12)

Prosedur yang dilakukan di kelas adalah mulai dengan adanya suatu permasalahan. Setelah diketahui ada masalah, dibuat perencanaan, kemudian dilaksanakan, diamati dan dilakukan refleksi. Setelah refleksi akan terlihat permasalahan yang tersisa yang merupakan masalah baru. Dengan adanya masalah baru maka dibuat perencanaan ulang, dilaksanakan, diamati dan dilakukan refleksi. Bila permasalahanbelum bisa diatasi maka dilanjutkan dengan siklus berikutnya.

Peneliti menetapkan subjek penelitian berdasarkan ketentuan bahwa anak pada kelas I semester I tahun pelajaran 2016/2017 SD Negeri 4 Tianyar masih belum memenuhi Kriteria Ketuntasan Minimal yang ditetapkan untuk mata pelajaran matematikayang jumlah keseluruhan siswa 32 orang. Objek penelitian ini adalah peningkatan prestasi belajar matematika anak pada kelas I semester I tahun pelajaran 2016/2017 SD Negeri 4 Tianyar setelah diterapkan model pembelajaran Kuantum dengan metode Snowball.

Penelitian tindakan kelas yang dilaksanakan di SD Negeri 4 Tianyar kelas I semester I tahun pelajaran 2016/2017 dari bulan Juli sampai dengan bulan November 2016. Metode pengumpulan datanya adalah tes. Metode analisis datanya deskriptif kuantitatif. Instrumen yang dipakai untuk mengumpulkan data adalah tes prestasi belajar. Indikator keberhasilan penelitian yang diusulkan dalam penelitian ini pada siklus I mencapai nilai rata-rata 57,66 dengan ketuntasan belajar 69\% dan pada siklus II mencapai nilai rata-rata 64,22 atau lebih dengan ketuntasan belajar minimal 91\%.

\section{Hasil dan Pembahasan}

Perencanaan sebuah penelitian harus dibuat dengan sangat matang agar dalam pelaksanaannya nanti bisa terarah. Untuk perencanaan ini dilakukan hal-hal: a) Menyusun rencana pelaksanaan pembelajaran (RPP) yang mengacu kepada kurikulum dan silabus, b) Menentukan kompetensi dasar/SK $\mathrm{KD}$, c) Menentukan indikator-indikator, d) Menentukan tujuan pembelajaran. Hal yang selanjutnya dilakukan adalah menentukan metode pembelajaran yang akan dilakukan. Langkah-langkahnya yaitu: a) Menentukan langkah-langkah kegiatan pembelajaran yang akan dilakukan, b) Menyusun LKS, c) Membuat lembar observasi, d) Menyusun penilaian terhadap prestasi belajar siswa, e) Menentukan langkah-langkah kegiatan pembelajaran yang akan dilakukan, f) Menyusun LKS, g) Membuat lembar observasi, h) Menyusun penilaian terhadap prestasi belajar siswa. 
Dalam pelaksanaan penelitian terdapat 3 tahapan yaitu: pertama pelaksanaan tindakan I, Setelah semua perencanaan tersusun sesuai dengan yang diharapkan, selanjutnya melakukan langkah-langkah sesuai perencanaan yaitu: a) Guru membuka pelajaran dengan doa bersama, b) Melaksanakan apersepsi dengan mengaitkan pelajaran yang lalu dengan yang akan diajarkan, c) Menginformasikan materi yang akan diajarkan/dibahas, d) Guru membagi siswa dalam bentuk kelompok, e) Guru menyajikan materi dan menyampaikan tugas yang akan dikerjakan dalam kelompok, f) Siswa di masing-masing kelompok diberi tugas untuk membuat soal matematika sesuai maeri dan tugas yang diberikan guru dalam kertas yang telah dibagikan, g) Kemudian kertas digulung seperti bola, h) Kertas yang telah digulung dilempar pada teman di kelompok lain, i) Siswa mengerjakan tugasnya, j) Guru mengadakan tes formatif. Thap kedua adalah Observasi/Pengamatan Siklus I. Tuntutan agar peneliti memperoleh data yang bisa dipertanggungjawabkanterlihatdalamobservasi yang dilakukanterhadaptuntutantersebut, maka peneliti melakukan: a) Dalam melakukan observasi, peneliti menggunakan jenis instrumen yang telah disusun sebelumnya dalam RPP, b) Semua tes yang telah dipersiapkan mengacu pada indikator dan komptensi siswa yang ingin diukur.

Hasil dari Siklus I diketahui prestasi belajar matematika siswa SD Negeri 4 Tianyar Kelas I Semester I Tahun Pelajaran 2016/2017 adalah dari 33 siswa 13 siswa memperoleh nilai yang baik atau tuntas sedangkan 10 siswa nilainya masih dibawah KKM atau tidak tuntas. Hasil tersebut diperoleh dari Refleksi Siklus I, Peneliti melakukan observasi dengan cara: mengawasi pelaksanaan tes agar siswa tidak bekerjasama untuk memperoleh data yang valid atau dapat dipertanggungjawabkan keabsahannya. Perolehan nilai siswa tersbut dimasukkan ke dalam data kela sinterval seperti pada Tabel 1 berikut.

Tabel 1. Data Kelas Interval Siklus I

\begin{tabular}{ccccc}
\hline $\begin{array}{c}\text { No } \\
\text { Urut }\end{array}$ & Interval & $\begin{array}{c}\text { Nilai } \\
\text { Tengah }\end{array}$ & $\begin{array}{c}\text { Frekuensi } \\
\text { Absolut }\end{array}$ & $\begin{array}{c}\text { Frekuensi } \\
\text { Relatif }\end{array}$ \\
\hline 1 & $40-45$ & 42,5 & 6 & 18,75 \\
\hline 2 & $46-51$ & 48,5 & 4 & 12,50 \\
\hline 3 & $52-57$ & 54,5 & 0 & 0,00 \\
\hline 4 & $58-63$ & 60,5 & 14 & 43,75 \\
\hline 5 & $64-69$ & 66,5 & 0 & 0,00 \\
\hline 6 & $70-75$ & 72,5 & 8 & 25,00 \\
\hline & Total & & 32 & 100 \\
\hline
\end{tabular}

1. Penyajian dalam bentuk grafik/histogram

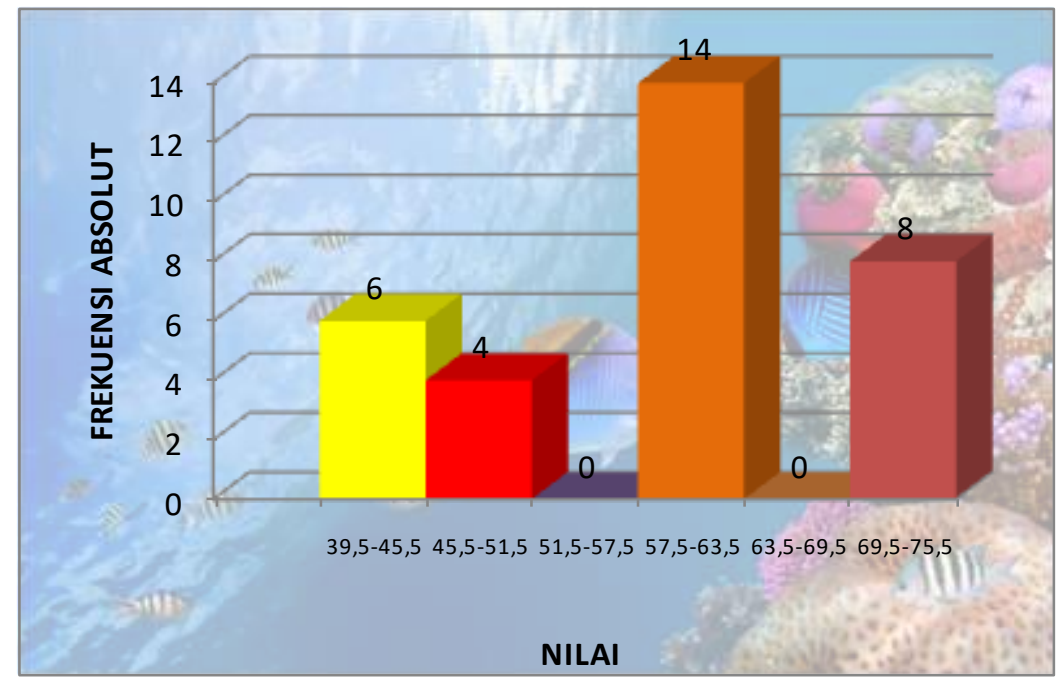

Gambar 02. Histogram Prestasi Belajar Matematika Siswa SD Negeri 4 Tianyar Kelas I Semester I Tahun Pelajaran 2016/2017Siklus I 
Siklus II terdiri dari 3 tahapan yaitu Pertama adalah tahap perencanaan. Rincian kegiatan yang dilakukan dari perencanaan penelitian ini adalah: a) Sebelum diadakan siklus II terlebih dahulu mencari kelemahan-kelemahan pada siklus I, b) Kemudian menyusun rencana pembelajaran tentang pelajaran Matematika dengan indikator sesuai dengan jadwal yang telah ditentukan, c) Menentukan metode-metode pembelajaran dan langkah-langkah yang akan dilakukan pada siklus II, d) Menentukan LKS sesuai dengan materi yang diajarkan, e) Menyusun penilaian formatif. Kedua adalah tahap Pelaksanaan Tindakan II. Setelah semua perencanaan tersusun sesuai dengan yang diharapkan, selanjutnya melakukan langkahlangkah sesuai dengan perencanaan yaitu: a) Membuka pelajaran dengan doa bersama, b) Melakukan apersepsi dengan mengaitkan pelajaran yang lalu dengan yang sekarang, c) Guru menyampaikan tujuan pembelajaran dan materi yang akan disampaikan, d) Guru membentuk kelompok dan menentukan ketuanya dan memanggil masing-masing ketua kelompok untuk memberikan penjelasan tentang materi, e) Masing-masing ketua kelompok kembali ke kelompoknya masing-masing kemudian menjelaskan materi yang disampaikan oleh guru kepada temannya, f) Masing-masing siswa diberikan 1 lembar kerja untuk menuliskan pertanyaan apa saja yang menyangkut materi yang sudah dijelaskan oleh ketua kelompok, g) Kertas tersebut dibuat seperti bola dan dilempar dari satu siswa ke siswa yang lain selama kurang lebih 5 menit, h) Setelah siswa mendapat satu bola/satu pertanyaan diberikan kesempatan untuk menjawab pertanyaan yang tertulis dalam kertas berbentuk bola secara bergantian, i) Guru memberikan kesimpulan, j) Evaluasi, k) Penutup dengan salam penutup. Tahap Ketiga adalah Observasi/PengamatanSiklus II. Peneliti melakukan observasi atau pengumpulan data melalui kegiatan berikut: a) Tes yang diberikan sudah tersusun baik sesuai perencanaan, b) Lembar observasi yang digunakan telah disusun sesuai kebenaran keilmuan yang tertulis pada kajian pustaka. Lembar ini dibawa ke kelas untuk mencek kebenaran perlakukan peserta didik.

Hasil dari Pelaksanaan Siklus II diketahui prestasi Belajar Matematika Siswa SD Negeri 4 Tianyar Kelas I Semester I Tahun Pelajaran 2016/2017 Siklus II adalah dari 32 siswa yang memperoleh nilai tuntas sebanyak 29 siswa dan 3 siswa memperoleh nilai belum tuntas atau di bawah KKM. Setelah dianalisis rata-rata nilai siswa adalah 64,22 yang artinya presentase ketuntasan siswa adalah $91 \%$. Perolehan nilai siswa dituangkan dalam data interval kelas Siklus II dan dalam bentuk grafik/histrogram yang bisa dilihat di bawah ini.

Tabel 04. Data Kelas Interval Siklus II

\begin{tabular}{lclll}
\hline $\begin{array}{l}\text { No } \\
\text { Urut }\end{array}$ & Interval & $\begin{array}{l}\text { Nilai } \\
\text { Tengah }\end{array}$ & $\begin{array}{l}\text { Frekuensi } \\
\text { Absolut }\end{array}$ & $\begin{array}{l}\text { Frekuensi } \\
\text { Relatif }\end{array}$ \\
\hline 1 & $50-55$ & 52,5 & 3 & 9,38 \\
\hline 2 & $56-61$ & 58,5 & 15 & 46,88 \\
\hline 3 & $62-67$ & 64,5 & 0 & 0,00 \\
\hline 4 & $68-73$ & 70,5 & 12 & 37,50 \\
\hline 5 & $74-79$ & 76,5 & 0 & 0,00 \\
\hline 6 & $80-85$ & 82,5 & 2 & 6,25 \\
\hline Total & & & 32 & 100 \\
\hline
\end{tabular}

Penyajian dalam bentuk grafik/histogram

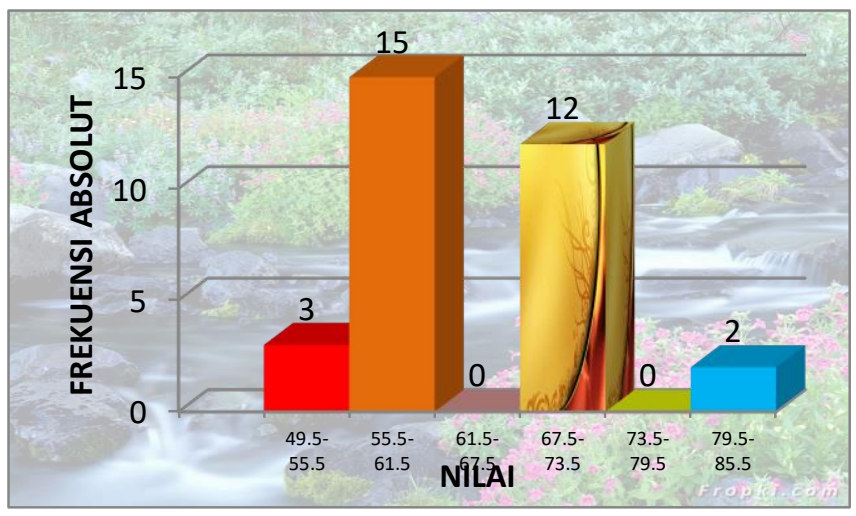

Gambar 03. Histogram Prestasi Belajar Matematika Siswa SD Negeri 4 Tianyar Kelas I Semester I Tahun Pelajaran 2016/2017 Siklus II 
Pembahasan hasil yang diperoleh di siklus I

Sesuai perolehan data awal yang amat rendah yang belum sesuai dengan harapan dan tuntutan indikator keberhasilan penelitian akibat hal-hal yang sudah diupayakan pada latar belakang masalah, maka pada siklus I diupayakan perbaikan dengan memilih model pembelajaran Kuantum dengan metode Snow ball. Model ini diupayakan pelaksanaannya di kelas secara maksimal dengan mengikuti teori-teori yang ada. Kendala yang ada adalah pada diri guru yang berlum terbiasa untuk melaksanakan dengan model yang baru ini dan masih terlintas pada pikiran bahwa tugas guru adalah mengajar dan belum betulbetul dimengerti bahwa sesuai aturan Permen yang baru tugas guru adalah membelajarkan. Kebiasaan ini masih muncul dan mendominasi pembelajaran pada siklus I. Peneliti pada siklus I ini masih tetap berdiri di depan kelas memperlihatkan diri bahwa kegiatan lebih pada mengajar. Hal ini akhirnya dipecahkan dengan kembali berdiskusi dengan guru-guru, bertanya jawab baik pada saat pertemuan awal maupun pada saat dilakukan pertemuan balikan. Peneliti giat melakukan diskusi, memberi pengertian-pengertian pada siswa dalam upaya menstimulir kegiatan yang dilakukan demi adanya perbaikan. Setelah giat dilakukan upaya untuk perbaikan akhirnya pada siklus I ini nilai siswa dapat meningkat walaupun belum sesuai harapan sesuai usulan keberhasilan penelitian. Kemampuan siswa awal dengan nilai rata-rata 53,75, akhirnya pada siklus I ini dapat ditingkatkan menjadi rata-rata 57,66 dengan ketuntasan belajar $69 \%$. kekurangan-kekurangan yang ada adalah masih terasa dominasi guru dalam pembelajaran, siswa belum giat bekerja, bertanya, berargumentasi, alat peraga/media belum mampu dioperasikan secara maksimal.

Pembahasan hasil yang diperoleh di siklus II.

Upaya yang lebih giat yang bisa peneliti laksanakan pada siklus yang kedua ini berpenekanan pada perbaikan-perbaikan dari kekurangan-kekurangan yang ada pada diri siswa maupun pada diri guru. Semua kekurangan pada siklus I yang sudah disampaikan menjadi acuan bagi peneliti untuk melakukan perbaikan. Perbaikan ini banyak dilakukan seperti membuat perencanaan pembelajaran yang lebih baik sebelum mereka masuk kelas. Pada saat melaksanakan proses pembelajaran bimbingan terus diupayakan diberi penekanan agar peserta didik merubah cara yang mereka belajar selama ini yaitu giat bekerja, giat mencari tahu, giat mengoptimalkan waktu pembelajaran untuk dapat menguasai materi yang diberikan. Jadi guru tidak diharapkan untuk menceramahkan materi, guru tidak diharapkan menghabiskan waktunya untuk berdiri di depan kelas dan ngomong a, b, c, terus menerus mendominasi kelas. Yang dituntut adalah lebih $60 \%$ waktu digunakan oleh siswa untuk memperoleh pengalaman belajar, jadi guru boleh duduk di bangku guru dan tidak harus terus menerus berdiri memberikan ceramah sampai habis waktu pembelajaran tetap juga berdiri. Pada pelaksanaan pembelajaran di siklus ini, bimbingan diupayakan lebih maksimal, arahan-arahan diberikan, tugas-tugas diberikan yang lebih menantang, agar siswa giat bertanya terhadap apa yang belum mampu dikuasai, mengupayakan pembelajaran yang menyenangkan, yang interaktif, inspiratif serta memberi ruang yang banyak bagi peserta didik untuk berkreasi, menyalurkan bakat serta memupuk keberhasilan siswa untuk berargumentasi, bentukan pendapat semua ini diupayakan dalam upaya memperbaiki kekurangan-kekurangan yang ada selama siklus I. Disamping itu peserta didik juga diminta untuk memperhatikan waktu dan tidak membuangbuang waktu pembelajaran. Diskusi yang matang arahan-arahan, bimbingan-bimbingan yang dilakukan ternyata mampu menghasilkan peningkatan yang cukup signifikan. Dari rata-rata siklus I 57,66 pada siklus yang ke II ininaik menjadi 64,22 dengan ketuntasan belajar 91\%. Keberhasilan ini tidak terlepas dari upaya yang sungguh-sungguh, upaya yang maksimal yang dapat ditujukan untuk peningkatan mutu pendidikan. Dari hasil tersebut, rumusan masalah disampaikan maupun dijawab, begitu juga tujuan penelitian mampu diupayakan. Dengan hasil tersebut maka hipotesis tindakan yang diajukan mampu dibuktikan kebenarannya. Oleh karenanya penelitian ini tidak dilanjutkan ke siklus berikutnya.

Penelitian ini sejalan dengan penelitian Sartika (2012) yang berjudul upaya meningkatkan hasil belajar siswa dengan menggunakan model pembelajaran kooperatif tipe snowball throwing pada mata pelajaran IPA di kelas V SD Negeri 147 Pemalang. Dari kedua penelitian tersebut semuanya memproleh hasil yang maksimal. penulis sebagai peneliti juga mengharapkan hasil yang sama seperti kedua peneliti diatas. Selain itu penelitian oleh Rahayu (2017) dan Susanti (2014) mengatakan model pembelajaran snowball throwing berpengaruh dalam meningkatkan hasil belajar siswa.

\section{Simpulan dan Saran}

Semua data pendukung pembuktian pencapaian tujuan pembelajaran dapat disampaikan bahwa model pembelajaran Kuantum dapat memberi jawaban yang diharapkan sesuai tujuan penelitian ini. Semua ini dapat dicapai adalah akibat kesiapan dan kerja keras peneliti dari sejak pembuatan proposal, review hal-hal yang belum bagus bersama teman-teman guru, penyusunan kisi-kisi dan instrumen penelitian, sampai pada pelaksanaan penelitian yang maksimal. 
Pencapaian kenaikan prestasi belajar siswa dapat dilihat dari bukti-bukti: a) Dari data awal ada 16 anak mendapat nilai di bawah KKM dan pada siklus I menurun menjadi 10 anak dan siklus II, 3 anak mendapat nilai dibawah KKM pada mata pelajaran Matematika. b) Dari rata-rata awal 53,75 naik menjadi 57,66 pada siklus I dan pada siklus II naik menjadi 64,22. c) Dari data awal siswa yang tuntas hanya 16anak sedangkan pada siklus I menjadi lebih banyak yaitu 22 anak dan pada siklus II menjadi 29 anak sudah tuntas.

Semua perolehan data hasil penelitian dalam upaya mencapai tujuan pembelajaran dalam bidang studi Matematika dapat disampaikan saran-saran: 1) Bagi guru-guru yang akan melaksanakan proses pembelajaran pada mata pelajaran Matematika, penggunaan model pembelajaran Kuantum semestinya menjadi pilihan dari beberapa model pembelajaran yang ada mengingat model ini telah terbukti dapat meningkatkan kerjasama, berkreasi, bertindak aktif, bertukar informasi, mengeluarkan pendapat, bertanya, berdiskusi, berargumentasi dan lain-lain. 2) Selanjutnya untuk adanya penguatan-penguatan, diharapkan bagi peneliti lain untuk melakukan penelitian lanjutan guna memverifikasi data hasil penelitian.

\section{Daftar Pustaka}

Azwar, Saifuddin. 1996. Tes Prestasi: Fungsi dan Pengembangan Pengukuran Prestasi Belajar. Yogyakarta: Pustaka Pelajar.

Darkasyi, Muhammad, Rahmah Johar, Anizar Ahmad. 2014. Peningkatan Kemampuan Komunikasi Matematis dan Motivasi Siswa dengan Pembelajaran Pendekatan Quantum Learning pada Siswa SMP Negeri 5 Lhokseumawe. Jurnal Didaktik Matematika Vol. 1, No. 1.

Depdiknas. 2011. Penelitian Tindakan Kelas. Direktorat Jendral Pendidikan Tinggi Departemen Pendidikan Nasional. Jakarta.

Dewi, Md. Puspa, I Kt. Adnyana Putra, I Gst. A. Oka Negara. 2014. Pengaruh Model Pembelajaran Snowball Throwing Terhadap Hasil Belajar Ipa Siswa Kelas V Sd Di Gugus Sri Kandi Kecamatan Denpasar Timur . E-journal Jurusan Pendidikan Guru Sekolah Dasar Universitas Pendidikan Ganesha.

Hamdu, Ghullam dan Lisa Agustina. 2011. Pengaruh Motivasi Belajar Siswa Terhadap Pestasi Belajar Ipa Di Sekolah Dasar. Jurnal Penelitian Pendidikan Vol. 12 No. 1.

Irawan, Zudi dan Agus Suharmanto. 2014. Perbedaan Hasil Belajar Kompetensi Menjelaskan Prosesproses Mesin Konversi Energi Menggunakan Model Pembelajaran Snowball Throwing Dengan Model Pembelajaran Langsung . Journal of Mechanical Engineering Learning , JMEL 3 (1).

Jampel, I Nyoman, I Wayan Widiana, Ni Made Yeni Juliantari. 2017. Inovasi Pembelajaran Saintifik Dengan Snowball Throwing Dalam Proses Menanya Terhadap Hasil Belajar Siswa. Jurnal Ilmu Sekolah Dasar Universitas Pendidikan Ganesha. Vol.1 (2) 128.-137.

Latipah, Eva. 2010. Strategi Self Regulated Learning dan Prestasi Belajar: Kajian Meta Analisis. Jurnal Psikologi Volume 37, NO. 1, JUNI 2010: 110 - 129.

Linto, Rendya Logina, Sri Elniati, dan Yusmet Rizal. 2012. Kemampuan Koneksi Matematis Dan Metode Pembelajaran Quantum Teaching Dengan Peta Pikiran. Jurnal Pendidikan Matematika Vol. 1 No. 1 Part 2 : Hal. 83-87.

Nugroho, Bagus Eko. 2016. Penerapan Model Pembelajaran Snowball Throwing Untuk Meningkatkan Aktivitas Siswa Dalam Proses Pembelajaran Serta Meningkatkan Hasil Belajar Matematika Siswa Kelas VIII Smp Pawyatan Daha 1 Kediri Materi Garis Lurus Tahun Pelajaran 2015/2016. Universistas Nusantara PGRI Kediri.

Pratama, Ery Rizki, 2014. Singgih Bektiarso, Agustiningsih Aplikasi Model Pembelajaran Quantum Teaching dengan Media Video Pembelajaran untuk Meningkatkan Aktivitas dan Hasil Belajar IPA Pokok Bahasan Daur Hidup Hewan Siswa Kelas IV SDN Sumbersari 02 Jembe. Universitas Jember. 
Putri, A.M S. Khanafiyah, H. Susanto. 2014. Penerapan Model Pembelajaran Kontekstual Dengan Pendekatan Snowball Throwing Untuk Mengembangkan Karakter Komunikatif Dan Rasa Ingin Tahu Siswa SMP. Unnes Physics Education Journal, UPJ 3 (1)

Rahayu, Ni Made Sri, I Wayan Sujana, DB. Kt. Ngurah Semara Putra. 2017. Pengaruh Model Pembelajaran Snowball Throwing Berbantuan Media Konkret Terhadap Kompetensi Pengetahuan Matematika Siswa Kelas V. e-Journal PGSD Universitas Pendidikan Ganesha Mimbar PGSD Vol: 5 No: 2

Safitri,Diyan Tunggal. 2011. “Model Pembelajaran Snowball Throwing Untuk Meningkatkan Hasil Belajar Matematika.

Sandi, I Kt, I Wyn. Suwatra, I Wyn. Widiana. 2014. Pengaruh Model Pembelajaran Snowball Throwing Terhadap Hasil Belajar Ipa Dengan Kovariabel Kemampuan Berpikir Kreatif Siswa Kelas IV SD. Jurnal Mimbar PGSD Universitas Pendidikan Ganesha Jurusan PGSD Vol: 2 No: 1

Sartika, Dewi.2012. Upaya Meningkatkan Hasil Belajar Siswa Dengan Menggunakan Model Pembelajaran Kooperatif Tipe snowball throwing Pada Mata Pelajaran IPA Di Kelas V SD Negeri 147 Pemalang.

Suprijono, Agus. 2009. Cooperative Learning. Jakarta: Pustaka Pelajar.

Sunarto. 2012. PengertianPrestasiBelajar. Fasilitatoridola [online].Tersedia: http://sunartombs.wordpress.com/2009/01/05/pengertian-prestasi-belajar/.

Susanti, Kd. Ayu, I Ngh. Suadnyana, Siti Zulaikha. 2014. Pengaruh Model Snowball Throwing Berbantuan Media Konkret Terhadap Hasil Belajar Ipa Kelas V Sd Gugusi Gusti Ngurah Rai Denpasar. e-Journal Mimbar PGSD Universitas Pendidikan Ganesha Jurusan PGSD Vol: 2 No: 1.

Wardhiana, I Km. Suka, I. G. A. Agung Sri Asri2, Ni Wyn. Suniasih. 2014. Penerapan Model Pembelajaran Kooperatif Tipe Snowball Throwing Untuk Meningkatkan Keaktifan Dan Hasil Belajar Pkn Kelas V Sd Negeri 1 Bungbungan. E-journal Jurusan Pendidikan Guru Sekolah Dasar.

Widiyaningsih, dan Pujiastuti, E. 2013. Keefektifan Pembelajaran Model Quantum Teaching Berbantuan Cabri 3D Terhadap Kemampuan Pemecahan Masalah. JURNAL KREANO, Jurusan Matematika FMIPA UNNES Volume 4 Nomor 1.

Widodo, P. Slamet.Jurnal Pendidikan Penabur. Meningkatkan Motivasi Siswa Bertanya melalui Metode Snowball-throwing dalam Pelajaran Pendidikan Kewarganegaraan No.13/Tahun ke-8/Desember 2009. 